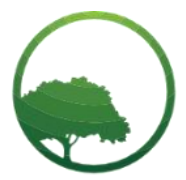

Business \& Social Science IJRBS

\section{Research in Business \& Social Science}

IJRBS VOL 9 NO 6 ISSN: 2147-4478

Available online at www.ssbfnet.com Journal homepage: https://www.ssbfnet.com/ojs/index.php/ijrbs

\title{
Key adaptations of SME restaurants in Malaysia amidst the COVID- 19 Pandemic
}

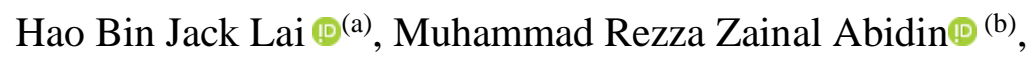 \\ Muhamad Zulfikri Hasni®(c), Muhammad Shahrim Ab Karim®(d), Farah Adibah Che Ishak® (e) \\ ${ }^{(a)}$ Department of Food Service and Management, Faculty of Food Science and Technology, Universiti Putra Malaysia, Selangor, Malaysia
}

\begin{tabular}{l} 
A R T I C L E I N F O \\
\hline Article history: \\
Received 05 October 2020 \\
Received in rev. form 14 Oct. 2020 \\
Accepted 18 October 2020 \\
\hline Keywords: \\
COVID-19; SME restaurants; \\
Pandemic management; Menu \\
development; Business viability; \\
Restaurant management \\
JEL Classification: \\
L1, L8
\end{tabular}

\begin{abstract}
A B S T R A C T
SME restaurants have reported declined earnings and faced challenges to remain open during the Movement Control Order (MCO) period imposed by the Malaysian government due to the Coronavirus (COVID-19) outbreak. SME decision-makers were observed to be making changes regarding their day-to-day operations and management strategies to mitigate MCO restrictions. This paper reviewed the significant adaptations made by SME restaurants in Malaysia throughout the MCO period through multiple primary and secondary literature utilizing a pragmatic approach. Three (3) prominent areas of adaptations made by decision-makers have been identified based upon ceaseless news reports and media contents. The adaptations made commonly depict actions to (i) Nurture Creativity, (ii) Sustain Reputation, and (iii) Maintain Profitability. The outcomes of this paper provide essential survival guides for SME restauranteurs to embrace the COVID-19 outbreak. These can help related policy and decision-makers implement the crucial traits of SME restaurants to reduce the impact on SME restaurants for the foreseeable future.
\end{abstract}

(C) 2020 by the authors. Licensee SSBFNET, Istanbul, Turkey. This article is an open access article distributed under the terms and conditions of the Creative Commons Attribution (CC BY) license (http://creativecommons.org/licenses/by/4.0/).

\section{Introduction}

The social-distancing order enforced to flatten the COVID-19 curve has disproportionally impacted Malaysia's restaurant sector. This has triggered the rapid shutdown of restaurants and hotels (Karim \& Haque, 2020). According to Marcus (2020) from UiTM's Faculty of Business and Management, small and medium-sized businesses (SMEs) were speculated to suffer bankruptcy, and larger businesses will be hesitant to employ more people due to this pandemic depriving the economy. That said, Bernama (2020) reported that food and beverage businesses had suffered a 90\% loss in revenue throughout the Malaysian Movement Control Order (MCO) period as compared to the previous year. Malaysia's government have since cooperated with the Malaysian Rating Corporation Berhad (MARC) to provide a "stimulus package" for SME businesses to ward off the economic disaster in the face of this outbreak, which includes: (i) SMEs receive a six-month moratorium on some government loans, (ii) RM5 billion worth of guarantees for SMEs that face difficulties in obtaining loans, (iii) RM4.5 billion of additional funds coming through three facilities targeted at micro-credit schemes, all-sector facilities, and a special relief facility, (iv) employers are also entitled to deferred payments, restructuring, and rescheduling of employer contributions to the employees' provident fund and a moratorium on Human Resources Development Fund (HDRF) payments for six months (Whitehead, 2020).

Nevertheless, these substantial initiatives were not widely applauded without their criticisms as well. Bernama and Afzanizam (2020) highlighted that governments need to take into consideration the effects of the entire food supply chain, including suppliers, landlords, producers, and restaurants, to determine the most optimum financial assistance for each industry. This is because the business environment varies among different industries. For this reason, the chief economist recommends that restaurants should focus more on improving services and menu offerings to sustain business viability instead of relying on government aids and support (Bernama \& Afzanizam, 2020). Essentially, Ismail (2020) emphasised that customers will still be anxious to dine at restaurants for the coming

* Corresponding author. ORCID ID: 0000-0001-8750-5658

(C) 2020 by the authors. Hosting by SSBFNET. Peer review under responsibility of Center for Strategic Studies in Business and Finance.

https://doi.org/10.20525/ijrbs.v9i6.916 
12 to 18 months. Henceforth, restaurants cannot depend only on takeaway and delivery options to sustain the MCO's aftereffects, especially when there are still high uncertainties in developing an effective vaccine.

This paper reviewed the significant adaptations made by SME restaurants in Malaysia throughout the MCO period through multiple primary and secondary literature utilizing a pragmatic approach. Three (3) prominent areas of adaptations made by decision-makers have been identified based upon ceaseless news reports and media contents. The adaptations made commonly depict actions to (i) Nurture Creativity, (ii) Sustain Reputation, and (iii) Maintain Profitability.

The organization of paper is as follows: This paper continues with a literature review based on the theoretical and conceptual background. Following this section, critical approaches have been introduced. Finally, this paper ends with a conclusion and future research direction.

\section{Theoretical and Conceptual Background}

\section{Movement Control Order (MCO)}

In compliance with the Malaysia Movement Control Order (MCO) restrictions that came on March 18 2020, to curb the pandemic outbreak, Malaysians' daily lives became very different overnight (National Security Council, 2020). The MCO will be prolonged unless the virus subsides, and hence restrictions that include the purchasing of supplies were tightened further.

The MCO is strictly enforced in the Klang Valley, Malaysia's most severely hit urban centre (Choo, 2020). The government is also aware of how this virus impacts the hospitality industry, both from a well-being and economic perspective. News of the lockdown came down hard on restaurants and eateries across the country, with strict regulations against patrons dining in. According to the National Security Council (2020), such locations might still be allowed to operate, but only to fulfil takeaway orders or deliveries. Restaurants are one of the hardest-hit establishments in this global pandemic. Empty dining rooms have become a common scene as people prefer to stay in rather than eat out. Many restaurants have started offering delivery services to ensure financial support during the crisis for their kitchen staff and service team. That said, restaurants are only allowed to provide takeaway services and prohibit customers from dining on-premise. Henceforth, robust efforts are crucial to prevent restaurants from facing capitulation. In this regard, restaurant decision-makers such as managers and chefs were observed to be making profound changes to their strategic and operational practices to cope with varying restrictions put in place by the authorities.

Even if the pandemic disappeared tomorrow, people would still have anxieties about dining out for a long time to come. With the MCO in effect, restaurants have resort to establishing an online presence and digital alternative to create visibility among consumers as a way to mitigate economic loss (Kapoor \& Vij, 2018). This has led to the growing popularity of being on food delivery platforms such as Grabfood, PetChef, Dahmakan, Bungkusit, RunningMan, Deliveroo, and FoodPanda promoting to a broader audience (Rathod, Khadke, Wakode, Ubnare, \& Shinde, 2018; Trupthi, Rakshitha Raj, Akshaya, \& Srilaxmi, 2019). On the other hand, restaurants have also utilised last-mile delivery providers such as Goget, Lalamove, and Mr.Speedy to deliver cooked meals for frequent consumers (see, Ekasari et al., 2019). This outbreak also continues to be an open problem that affects up-scale restaurants that are more accustomed to serving customised courses on fine-china bones rather than Chicken Au Poivre in Styrofoam boxes, and this may seem incongruous (Choo, 2020). But the fact is that restaurants are cash-reliant businesses; no kitchen operation means no sales.

\section{Maintaining Restaurant Business Viability During a Crisis}

Although there may be government provisions to support SMEs in the short term, it will require a great deal of customers' credence for restaurants to stay afloat. A restaurant typically depends on many factors to maintain business viability. According to SME Corp (2016), SMEs restaurants are categorised as businesses that employ less than 75 employees or have a turnover of less than RM 20 million per annum.

Prior to the COVID-9 outbreak, Ernst and Young (2020) reported that SME restaurants in Malaysia have been facing aggressive competition against established foodservice brands. In fact, 30.7\% of Malaysian service-based SMEs operate within Klang Valley, which constitutes a very high concentration (CIMB Bank, 2019). Despite that, restaurants were able to implement strategies to retain a loyal customer base by providing quality food and timely service in a comfortable ambience (Jain, 2020).

Ensuing this pandemic, restaurant consumption behaviour is expected to change tremendously as social distancing and hygiene precautions discourage the urge to visit crowded establishments. While large chain and franchise restaurants may thrive because of their brand confidence and consistency in hygiene control that is involved in preparing the food, it is the small to mid-scale SME restaurants that will suffer (Mah, 2020). As reported by Surendran (2020), micro SMEs have even resorted to raising funds through peer-to-peer lending platforms to keep their businesses afloat. For that reason, it is worth reviewing the consequences of the COVID19 crisis and portrays the best practices done by SME restaurants to sustain business viability.

According to Bae, Slevitch, and Tomas (2018), there are many attributes, such as the service, food quality, and ambience, that define a good restaurant that yields a satisfactory dining experience. However, from a business perspective, a profitable restaurant needs to generate a reasonable return by providing sufficient value towards diners considering both the internal and external business environment (Osterwalder \& Pigneur, 2010). Internally, restaurants are required to restructure their strategy, rethink their offerings, 
and (re)optimise their resources. Externally, restaurants need to be consistently responsive to changes in political, environmental, social, and technological factors (Aguilar, 1967; Porter, 1998).

This reflects being effective in monitoring costs and consistently implementing a pricing strategy to ensure that the business stays afloat (Uman, 1983). Furthermore, restaurants must be agile and creative in making quick decisions to adapt to the latest trends and consumer behaviour (Aguilera, 2017). Finally, restaurants should define a clear positioning within their locality or industry to create returning and loyal customers through exceptional goodwill and brand value (Andersson \& Mossberg, 2004). This paper aims to review the prominent adaptations made by SME restaurants in Malaysia to provide managerial implications and directions for future research. This paper will look at the prominent adaptations through the core elements to sustaining business viability in the restaurant industry: (i) Nurture Creativity, (ii) Sustain Reputation, and most importantly (iii) Maintain Profitability.

Outcomes from this paper will: (i) provide insights and best practices for existing restaurants that have not taken action, (ii) serve as a post-COVID-19 precaution guide for aspiring SME restaurant operators and entrepreneurs, (iii) suggest better policies that can be implemented by the government to reduce the impact towards SME restaurants for the coming future.

\section{Nurturing Creativity in Menu Development to Improvise and Adapt}

Over the years, creativity has spawned significant interest in management studies among academic researchers (Ramos, Anderson, Peiró, \& Zijlstra, 2016; Slavich \& Svejenova, 2016). The role of creativity and innovation in any organisations' long-term survival is broadly recognised - and not only in so-called creative industries (Unsworth, 2001). In fact, creativity benefits any organisation in many activities, well beyond the explicit role of creativity in the field of new product development. Hence, managing creativity is, therefore essential to achieve organisational performance and success (Anderson, Potočnik, \& Zhou, 2014). It has been widely acknowledged to lead to a competitive advantage over time (Sousa, Pellissier, \& Monteiro, 2012; Unsworth, 2001). The ideologies of creativity and innovation in up-scale restaurants have intensified, underlining the significance of chefs who are constantly committed to identifying, developing, and introducing creative menus that meet customer expectations and achieve sustainable performance (Albors-Garrigos, Barreto, García-Segovia, Martínez-Monzó, \& Hervás-Oliver, 2013; Bouty \& Gomez, 2013; Ottenbacher \& Harrington, 2007; Zainal Abidin, Che Ishak, Ismail, \& Juhari, 2020),. Thus, chefs are accustomed continuously to reinventing new ideas into new products and services, creatively experimenting with new and/or traditional food-components and their interactions (Vargas-Sánchez \& Lopez-Guzman, 2015; Zainal Abidin et al., 2020).

The area of creativity has become an increasingly important determinant of business performance, and long-term sustainability is often conceptualised as the ability to generate novel and innovative ideas (Amabile, 1988; Amabile, Barsade, Mueller, \& Staw, 2005). Contextually, this section aims to exemplify how restaurants optimise their creativity during this critical COVID-19 outbreak. What are they doing? Are they the improvising? Are they creatively executing a well-developed menu? Paradoxically, are they reinnovating menus to adapt to the current crisis?

\section{Reinforcing Skills and Creativity}

In a modern context, chefs can be seen as designers (Kudrowitz, Oxborough, Choi, \& Stover, 2014). Their professional kitchens serve as design studios and manufacturing plants, innovating and transforming ingredients for small-scale production. The outcome is an edible consumer product requiring design to invoke complex and uncomplex menus to fulfil hunger. To do so, the chef must truly consider their target market to produce appropriate and appealing items. They must constantly tailor to emerging trends and consumer needs to sustain their product's long term viability (Aguilera, 2017).

Embracing this outbreak, the chefs cook with whatever items they can obtain as delivery services are now minimal. The kitchen team is diligent in looking into any substantial ingredients and incentive values to integrate into their work. Still, frankly, nothing is fixed, and it is time to improvise creatively. For instance, Dewakan, the revolutionary Modern Malaysian restaurant, chose to close the business and take this time to refine its skills (Choo, 2020). At Dewakan, they took the MCO extension as a medium of opportunity to intensify the team R\&D skills by experimenting with juice pairings on chocolate products. Thus, allegedly, Teoh and his team were willing to embrace certain "loses" and use the MCO extension wisely to ameliorate their menu and nurture the team creativity rather than to be or to stay at par.

\section{Menu Simplification}

Although "fresh" is an adjective applied to many restaurants in the production of high-quality meals, preserved food, and retail food products may be making a comeback, and it starts with chefs. This is due to a disruption in the MCO's food supply chain, limiting the services offered by wholesalers and suppliers and hence confined the availability of fresh produce (Kaur, 2020). As a result, restaurants have reiterated menu items to adapt to this limitation. Up-scale restaurants have cut down the selections on their menus and, instead, go back to basics featuring refined good quality comfort foods at an affordable price point (Burhan, 2020). This is done in response to cope with the economic downturn as household expenditures are decreased due to the deprioritisation of non-essential businesses such as up-scale restaurants (Kaur, 2020).

For restaurants who are already offering comfort foods, Ismail (2020) highlighted that decision-makers had reduced their menu offerings to focus only on sturdy menu items that travel well in takeaway boxes. Furthermore, restaurants were observed to be currently serving a more simplified version of their menu utilising more preserved food products (e.g., smoked sausages, cured meats, 
canned beans, frozen fruits, pickled vegetables, dried nuts, and fermented pastes) as core ingredients. This might motivate the chefs to favour the need for an alternative approach to (re)develop the menu using these functional food products. Indeed, most chefs rely on fresh produce to ensure their highbrow standard, and for Michelin-star chefs, the so-called ego mayhap rubs on their faces. With the current crisis lashes, they were forced to "downgrade" the standard to cope with the supplies shortage; otherwise, they might face a significant financial crisis. For instance, the co-owner of Awesome Canteen ${ }^{1}$, Diane Ong has turned to brine their salmon fillets and smoking their beef cuts to prolong the products' shelf-life (Yi, 2020). In deduction, utilising preserved food products and simplifying the menu's offerings are essential to reduce wastage and control costs to cope with demand uncertainty throughout the crisis.

\section{Restaurants' Implementations of Providing Retail Food Items}

With the MCO encouraging people to stay home, many consumers prefer to purchase groceries and pre-cooked items from supermarkets that can be stored for many days to reduce the chance of going out. Although preserved and processed food products are not always seen as nutritious in the United Kingdom, 66\% of people affirmed that they do not feel "bad" after indulging them, making clear that even high-calorie counts do not interfere with the functional food trend (Devitt, 2020).

Furthermore, consumers prefer to prepare their meals to reduce the chances of getting infected by delivery riders. For that reason, restaurants were quick to expand their offerings to provide retail food items such as marinated meats, handmade condiments, and premixed beverages. For instance, Ember Modern Bistro $(2020)^{2}$ and Fittie Sense Restaurant $(2020)^{3}$ offer homemade butter, jam, and kimchi, while Eurodeli Restaurant (2020) ${ }^{4}$ and the Butcher's Table promote frozen raw and cured meat products such as sausages and bacon that can be kept for months. There are even restaurants selling groceries to households due to the shortage of fresh produce at the supermarket. As a result, new streams of income were created by listening to what customers want.

\section{Consideration Between Heated to Order or Cooked to Order?}

It is not a smooth transition for restaurants known for their elegant service and exquisite cuisine. An up-scale restaurant's allure dwells in more than just the food, which, when coerced out of the dining room, must be packed into environmentally sound alternatives such as lavish cardboard boxes (Tan, 2020). On the contrary, in the case of Sunbather Coffee ${ }^{5}$, an initial delivery trial for a few days saw the Bangsar South cafe facing delivery issues. According to Yi's (2020) article, restaurants recognised that upon delivery, the quality of a restaurant's food might be jeopardised due to sluggish delivery services could be. Often delivery riders might arrive late, resulting in customers receiving unsatisfactory "cold-meals". That said, restaurants prefer to package "pre-cooked" and "pre-made" meals that can be heated up or prepared easily at home at the diners' leisure. Since the food items are delivered in vacuum-sealed plastic bags, food hygiene is assured when no one can interfere with the food.

\section{Enhancing Brand Reputation and Loyalty to Keep Customers Coming Back}

The dining experiences play a prominent role in consumer repurchase intention in any typical restaurant establishment (ChenTsang(Simon) \& Pei-Hsun, 2012). The role dining experiences serve as guidance in delivering the true originality of one restaurant value and identity. Restaurants heavily rely on providing an exclusive and memorable experience to every diner to motivate repurchase intentions (Gaytan, 2008). Dining experiences can be divided into physical criteria such as food, services being offered, service personnel, and restaurant atmosphere (Andersson \& Mossberg, 2004; Sukalakamala \& Boyce, 2007). Similarly, the restaurant atmosphere plays a significant role in providing a memorable experience for diners (Ryu, 2011). An establishment's design and atmosphere deliver a sensual encounter for diners, thus developing a unique experience when dining inside a restaurant (Maharlika, 2020).

\section{Are the Takeaway Boxes a Chef's Nightmare or Playground?}

Delivering food in a Styrofoam container and paper boxes is not a common practice of up-scale restaurants. In coping with the current pandemic situation where restaurants rely on takeaway meals and delivery services to generate cash flow, decision-makers are trying to come up with ways to present a similar dining experience resembling their restaurant identity inside a takeaway box.

During this desperate crisis, restaurants need to remain genuine and authentic despite adapting more cost-efficient food preparation practices (Severson \& Moskin, 2020). To illustrate, chef Grey of Liath ${ }^{6}$ alluded that the restaurant has heightened the level of practising takeaway and dine-out of the restaurant in a fun way. Whereby, the core-value of the restaurant identity, "fun while dining", being a significant part of the takeaway concept. Instead of providing fully-customised meals, Grey purposely includes an "instruction-manual" to be followed by customers to rearrange and complete the meals by themselves at home (Digby, 2020). Thus, this small gesture has indirectly created a trend on social media whereby diners are sharing online the entire process of arranging,

\footnotetext{
${ }^{1}$ Awesome Canteen is an independent café with modern rustic-touched, offering warm comfort café style menu.

${ }^{2}$ Ember is a modern-concept bistro that offers contemporary Asian cuisine.

${ }^{3}$ Fittie Sense is a subculture of health-inspired restaurant that offers healthy foods.

${ }^{4}$ Euro Deli is casual restaurant specialising in forced meat products and sausages.

${ }^{5}$ Sunbather Coffee is a Japanese-inspired café with a twist of European and Western interpretation in their menu.

${ }^{6}$ Liath is a one-star Michelin fine-dining restaurant located in County Dublin, Ireland.
} 
plating, and creatively presenting takeaway meals. Such an experience provides unique value for diners to personally experience the full pleasure of cooking customised meals at home.

The concept concocted by chef Grey appears to bear some resemblance in a way that is done by Malaysian modernist chef Darren Teoh of Dewakan ${ }^{7}$. Likewise, Teoh offers their takeaway meals by providing do-it-yourself (DIY) food-kits, called "Cook Like Dewakan", conserving the originality and authentic connotation of the Dewakan brand (Choo, 2020; Wei, 2020). Herein, Dewakan aims to exercise facets of its strength and core beliefs, even in their takeaway meals. This demonstrates the importance of offering brand-value focused products, even during a pandemic crisis.

In a similar vein, myBurgerlab ${ }^{8}$ turned this unforgiving pandemic into an opportunity by offering a takeaway service pack where customers can customise and cook their own-version of burgers at home with family (Liu, 2020). This unique experience shows how myBurgerlab delivers its value through the concept of "cooking at home", and it truly signifies the epithet of myBurgerlab in encouraging consumers to craft their burger in their own "lab".

"We want to encourage people to cook their own food, so we're working on a takeaway pack where consumers can customise and cook their own burger, and go crazy at home! It literally becomes, 'my Burgerlab"' - RenYi Chin

Among all the creative take away and delivery concepts, Saint Pierre ${ }^{9}$ restaurant proved that takeaway could also be exclusive and elegant. With just a few adjustments and initiatives, the restaurant has taken measures to provide more memorable dining moments at home far away from your loved ones. Meals that are ordered from the restaurant will be personally delivered by restaurant waiters dressed in suits, and diners will be given a link to attend an online video conference. The chef himself will greet diners at the video conference, which can be accessed by friends and family members at different locations. Thereafter, diners can enjoy the meal amongst each other, interacting through the video conferencing apps as if they were dining together at Saint Pierre's restaurant (Loh, 2020). Consequently, the concept of eating alone during this pandemic can now be avoided through what is being considered as "virtual dining experiences" that can be enjoyed together by most of the family members and friends miles away, virtually (Tan, 2020).

\section{Giving Back to the Customers and Community}

Indeed, the SME restaurant industry is among the sectors facing economic distress ever since the news of COVID-19 broke in Malaysia. People are opting more for deliveries, causing foot-traffic to drop significantly. When the Malaysian Prime Minister announced the MCO news, a lot of restaurant owners operate fragmentarily through pick-ups and delivery. At the same time, some opt to close their operation temporarily until the MCO is lifted.

In the present situation, restaurant owners and chefs face a lot of pressure, culminating in some of them being a little creative. In contrast, some restaurants plan to reduce the workforce or switch entirely to delivery platforms, and one restaurant found a new lateral in combating the worsening outbreak. The unsung duo heroes, chef Chai Chun Boon and his wife, Zeehan Zahari of Copper ${ }^{10}$ explained how they managed the business during the lockdown. The owner stated that even the day before the MCO announcement, they saw an $80 \%$ drop in sales as companies within the Copper building had started to allow their employees to work from home (Choo, 2020). While trying to find alternatives to replicate similar businesses worldwide, Zeehan Zahari found a post on Instagram calling for fundraising to provide food to healthcare professionals as they work tirelessly to care for COVID-19 patients. Many frontliners do not even have the time to sit down for a rest, let alone go out to buy food for themselves, which motivated Zeehan to help the nation's frontliners by providing packed food with donors' support. In this scenario, the team and operations could stay afloat. At the same time, restaurateurs could even help the local farmers, suppliers, artisans, and distributors who are part of the supply chain (Wan, 2020). Nando's Group is also adapting the same practices wherein the company feels obligated to giving back to the community even before the MCO began by donating over 5000 meals to local hospitals and food banks. Furthermore, they also gave frontliners a $40 \%$ discount. Via their robust loyalty app database, they encouraged people to donate loyalty points to charity by donating 3 points, the RELA (Jabatan Sukarelawan Malaysia), health care providers, police, and the army will receive a 1/4 chicken meal (New Straight Times, 2020).

On the contrary, Darren Chin, the head chef of DC restaurant ${ }^{11}$ and Bref ${ }^{12}$ took a different approach in inventing and developing his creativity to grapple with the COVID-19 outbreak. Instead of following "takeaway trends", Chin opted to conduct live cooking demonstrations on his Facebook page where he reveals the secrets to his cooking techniques and applying those techniques to simple yet tasty recipes that can be followed by home-cooks (Choo, 2020). Remarkably, his approach received amounts of constructive feedbacks from his followers. Acting upon all the feedback, Chin came up with a special home-cooked takeaway menu centred on offering comfort food, which is usually not offered in his upscale restaurants. This strategy further strengthens Chin's branding and authentic hospitality in creating loyal returning customers. Chin's approach of utilising his creativity in generating new ideas as a

\footnotetext{
${ }^{7}$ Dewakan is an Award-Winning Restaurant which currently on Asia's 50 Best Restaurants list at $46^{\text {th }}$ place with the title of Best Restaurant in Malaysia.

${ }^{8}$ myBurgerlab is a hipster dine-in restaurant that offers crafted burgers with fresh homemade buns and patties.

${ }^{9}$ Saint Pierre is a fine-dining restaurant that offered muti-course seasonal menus, currently holding one Michelin star.

${ }^{10}$ Copper is a semi-casual, modern European restaurant operating since January 2015.

${ }^{11}$ DC restaurant is one of most influential fine-ding scenes in Malaysia focusing on modern French cuisine.

${ }^{12}$ Bref is a branch of DC restaurant by Chef Dareen Chin with a more casual, warm, and cosy spin-off ambience. The menu offered is a French-influenced cuisine.
} 
social process resonates with Perry-Smith and Mannucci's (2017) work whereby new ideas are generated through an evolving networking process when the audience (diners) are embedded in the creative process of developing a menu.

"DC and Bref are both gastronomic restaurants. We decided not to do takeaway or delivery meals... and instead use this time for rest, reflection and research." - Darren Chin

\section{Maintaining a Restaurant's Identity}

The restrictions and regulations ruled out by the government have significantly disrupted the mainstay of the hospitality business of selling unique experiences, good food, and accommodative services. For certain SME restaurants, adaptations that may seem irrelevant before became one of the essential strategies to achieving survivability during the current economic phase. De facto, what's more relevant for the restauranteur is the sense of "identity-presence" that is most sought after a reputable business identity is mainly derived from the core of acceptance by the consumer ( $\mathrm{He}, \mathrm{Li}, \&$ Harris, 2012).

Most restaurants put a massive amount of energy, time, and money into building their own unique and niches for their business identity in the industry. This niche or uniqueness signifies a restaurant's core competency to capture consumer attention and admirability towards what they offer (Chua, Jin, Lee, \& Goh, 2014; Walls, Okumus, Wang, \& Kwun, 2011). Yet today, as takeaway practices become the new normal, a restaurant must adapt accordingly to maintain the value of their business identity. Most often, the practices of takeaway portrayed a lack of exclusivity, presentation, and personalisation to represent a restaurant's identity, whereby it was even considered to be "offensive" loomed by some chefs from upscale restaurants (Bray, 2020).

However, rivalries in the restaurant industry have become fiercer because of the pandemic outbreak, and today, many restaurants are struggling to seek out new strategies so that it does not lose customers. Moreover, we live in an "experience economy" in which customers are becoming more and more susceptive to seek out experiences that intrigue, innovate, and inspire (Pine \& Gilmore, 1998). Hence, restaurants are expected to create a unique and distinct takeaway experience to entice the customers. Moreover, the concept of takeaway is not merely adaptable by some restaurants. The product identity and restaurant value need to be conveyed while delivering in takeaway boxes. Recent information opined by the Hong Kong-based Full Service Restaurants Company, JIA Group, revealed that some SMEs considered the best measures were to provide dishes in line with their restaurant concept and quality value by sourcing customised packaging and containers to maintain temperature and food quality (Bray, 2020).

\section{Maintaining a Quality Experience Through Takeaway Meals}

The offering of DIY kits are used as a medium to deliver a restaurant's core strength, value, and identity, providing an entertaining new experience for diners (Choo, 2020; Digby, 2020; Liu, 2020; Yi, 2020). These DIY kits typically consist of marinated proteins, reheatable sauces with preserved garnishes and accompaniments. Born out of the MCO restriction, upscale restaurants such as Beta and Bref sell DIY kits accompanied with simple professional cooking instructions as an offering to provide valuable experiences for diners to enjoy from the comfort of their home kitchens. Rather than offering typical ways of obtaining cooked food from takeaway and deliveries, restaurant DIY kits empower consumers to become their own chefs in obtaining a quality home-cooked meal without stepping outside of the house (Lim, 2020). Some restaurants used DIY kits as a platform to share knowledge with consumers to customise their selections of protein, ingredients, and sauces. As a result, this adaptation solves the delivery dilemma while ensuring that their meals are enjoyed at optimal temperatures during the leisure of the consumer.

A restaurant needs to manage consumer expectations to deliver services that align with target market needs (Andersson \& Mossberg, 2004). Every successful restaurant aims to make sure diners can fully experience the value that is being delivered. Value, in which, varies based on the location, level of service, and target clientele of the restaurant, creating memorable dining experiences and repurchase intentions.

Thus, with considerations of the current pandemic situation that discourages dining out in public spaces, restaurants need to be pragmatic in maintaining restaurant brand value and consistent dining experiences while adapting takeaway and delivery practices to sustain business viability.

\section{Managing Financial Viability to Stay Afloat}

Finally, a restaurant's performance is generally reflected in their profit and loss statements. A restaurant may seem like they are making money because it is always crowded, but if the margins are not optimal, they may be losing money instead. Similarly, a restaurant may have excellent margins per menu item sold, but if there is not enough demand for their menus, any restaurant will also fail if operating overheads and production costs are not controlled. The proof is in the pudding, whereby famous hotels and bars have shut down despite their recognition and awards as it is not viable to continue doing business due to weak financial management (Chan, Hassan, \& Boo, 2014; Chong, 2012). Therefore, it is vital to reflect on the profit potential when making restaurant management decisions. The key here is to identify operational inefficiencies by managing the profitability of every menu item (Ozdemir \& Caliskan, 2014; Taylor \& Brown, 2007).

As emphasised by Ozdemir and Caliskan (2014), this scenario of overlooking a menu's profitability is a challenge for decisionmakers, and the consequences will become more severe in pursuing this pandemic outbreak. This is evident, according to Durai (2020), who interviewed SME restaurants in Klang Valley, none of the restaurants was prepared to adapt their business models to 
rely on food delivery and takeaways to survive. Because of that, these restaurants are operating at a loss. Addedly, even restaurants who were operating at high delivery and takeaway volumes throughout the MCO, such as myBurgerlab, also were not making a profit at all. This was partly due to high commissions of $20 \%$ to $35 \%$ per order imposed by food delivery services resulting in the managers having to suffer pay cuts to keep the restaurant afloat (Grunebaum, 2020). Likewise, the Malaysian Muslim Restaurant Owners Association (PRESMA) has also reported that Mamak restaurants suffered an $80 \%$ revenue loss since the MCO was imposed and had difficulties surviving due to their high operating costs (Azman, 2020).

Hence, to overcome these hurdles, a restaurant must be able to manage menu profitability. From a practical perspective, managers can adhere to several principles and concepts to minimise costs and optimise margins. Restaurants should devise adaptive menu items that utilise shelf-stable ingredients. At the same time, menu items that incur the highest production costs and storage costs are to be thoroughly reviewed. Consequently, restaurants should promote menu items that speak the brand value, thereby developing a sustainable competitive advantage by having loyal customers and carving a niche for being specialised in providing a menu item. Finally, restaurant decision-makers must gauge market conditions and be adaptive in allocating labour, adjusting menu pricing, and modifying menu production specifications.

\section{Emphasizing Festivities and Celebrations to Improve Average Checks}

In large cities, dining out in the month of Ramadhan is often a popular practice for Malaysians (Mohd Zahari, Fatah, Fatah, \& Hafiz, 2017). However, according to the announcement made by the Minister of Klang Valley, Dato Seri Amirudin Shari, a decision has been made to cancel the Bazaar Ramadhan for the year 2020, due to the pandemic crisis as recommended by the Ministry of Health Malaysia (Che Noh, 2020). Furthermore, the Senior Minister (Defence), Datuk Seri Ismail Yaakob, stated that there would be no easing of restrictions regarding restaurants operating during the fasting month (Mohsen, 2020). This directly impacts the profitability of many restaurants that would normally organise Iftar Ramadhan buffets. For many restaurants, the Ramadhan month generates a hefty revenue due to the sheer high volume and demand of Malaysians wanting to celebrate and gather (Hasan, 2019).

For that reason, creative family restaurants such as De.Wan $1958^{13}$ by Chef Dato' Redzuawan Ismail and Table and Apron ${ }^{14}$ partially restructured their serving concept by introducing deliveries and takeaways of family sets for 4 to 5 pax suited for celebrating the Ramadhan at home: "MCO Takeaway \& Delivery Menu" and "Ramadhan Feast In A Box". Furthermore, De.Wan restaurant even implemented a rotating daily menu whereby families can pre-book their desired meal dishes. This makes it manageable for restaurants to reduce wastage and forecast expected demand. At the same time, offering rotating menus would entice diners to try something from the restaurant every day.

\section{Increase in Consumers That Value Convenience and Affordability}

The concept of doing takeaways is not new to cafés and fast-food restaurants, hence adaptions were straight forward. However, upscale restaurants who previously discouraged take away meals had no choice but to provide take away services to maintain cash flow (Durai, 2020). As upscale restaurants adapt their business model to cater to takeaway deliveries, they are no longer limited to their seating capacity. Instead, they must streamline productivity and efficiency without compromising quality.

This was also an excellent opportunity for up-scale restaurants to offer a simplified version of their menu at an affordable price to attract a wider audience of diners, leveraging its brand value. The exploration of serving a whole new market is beneficial to create volume and consistency for the business, as previously, diners would only visit up-scale restaurants during special occasions. To generate more cash flow, restaurants have also turned to sell prepaid vouchers applicable for future use at a discounted price as a further incentive for loyal customers.

During times like this, where the economic activity is slow, consumers tend to face anxieties of job insecurity and income instability. Hence, consumer behaviour has changed to became much more cost-conscious and perceives more value in appropriacy (Kanyakumari, 2020).

\section{Optimising Every Employees' Presence to Create More Value}

Working in a restaurant is very different from working at offices, where most workers are performed through the computer, providing an easy transition to work remotely (work from home), especially during the MCO period. Restaurants face considerable discrepancies because restaurant employees perform operational roles, which means that they cannot perform their job if they are not in the restaurant.

Hence, for the case of restaurants, it takes a different approach to provide job security for restaurant employees. With the introduction of new menu items and different distribution strategies, restaurants reorganise existing employee roles to adapt to this situation. Decision-makers would now adjust kitchen stations to become more production-focused instead of service-focused, as most menu items will resemble retail packaged food items that are developed to be more rigid and durable to overcome the uncertainties of

\footnotetext{
${ }^{13}$ De.Wan 1958 is an up-scale modern Malaysian restaurant that serves variety of Malaysian cuisines with modern-touched inspirations.

${ }^{14}$ Table and Apron is a casual-dining restaurant that offers cosy, bistro-style menu.
} 
delivery timing and demand. Similarly, front of house employees will perform more administrative tasks such as taking orders over the phone, organising pre-orders, and even becoming delivery drivers.

\section{Offer Pre-Order Options and Enforce Minimum Delivery Costs}

Throughout the MCO period, if a restaurant decides to stay open, it must optimise the limited operational hours and reduce overhead costs. Proper cost control and revenue management to optimise operational efficiency is key to survivability (Lai, Karim, Krauss, \& Ishak, 2019). Multi-outlet restaurants have shut down redundant outlets and operate out of a single central kitchen to maintain cash flow while reducing operational costs.

Because most order transactions are performed online, and over the phone at the comfort of their own homes, the sense of impatience will be reduced drastically. Likewise, during the MCO, consumers have become more understanding, whereby it may take a long time for their food to arrive due to the high demand for delivery orders during peak hours. Hence, consumers who wish to avoid long delivery times were encouraged to pre-order for future days. From the restaurant's perspective, this change in consumer behaviour meant that restaurants could better manage consumer expectations by designating pick-up times and forecast demand to stock up kitchen inventory adequately. This example can be observed in myBurgerlab whereby they encourage customers to order at least 30 minutes prior so that customers can pick up their orders when they arrive, to prevent people from crowding within their restaurants (Yap, 2020).

As restaurants depend more on delivery platforms to get their food delivered to consumers, the fees charged by delivery platforms range between $20 \%$ to $35 \%$ of the restaurant sales revenue, creating a new category of variable cost for restaurants. For that reason, restaurants with low margins will impose a minimum order value on a single bill to cover delivery costs.

\section{Moving Forward: The New Normal Post Covid-19}

It is no surprise that SME restaurants across the country are taking a hit from the COVID-19 crisis. As the outbreak will likely continue and even deteriorate for some time, the authorities encourage people to stay home. While some businesses are open to having their workers operate remotely, others cannot. Small businesses will also be negatively impacted when people go out less and turn to alternative means of shopping. Hence, restaurants will face higher operational costs to provide delivery packaging, sanitisation, and personal protective equipment when preparing meals. To brace themselves for the effects of COVID-19, SME restaurants will need to act decisively and prepare to take advantage of the recovery (see, Mandabach et al., 2011; Lynch et al., 2012).

Thus, based upon this review from a political standpoint, it is evident that if there is no vaccine developed for this pandemic, restaurants are unlikely to return to pre-pandemic performance. However, governments can take further measures to reduce this impact on SME restaurants if there are subsidy or exceptions to curb the high commission fee imposed by food delivery platforms and offer service-tax breaks (Azman, 2020). Through analysing the deflating gasoline prices in the country as reported by Kana (2020b), it is very unfair for restaurants to still fork out large chunks of delivery fees while the demand for delivery and courier services is surging.

Judging from the current restaurant business environment, the pandemic result has led to a change in consumer behaviours. It will create a new normal among eating habits, spending ability, and movement patterns (Kaur, 2020). On the other hand, Chan (2020) stressed that businesses would have to be vigilant when accommodating these new consumer behaviours through improving financial resilience, business models, and technological fluency. Correspondingly, most restaurant businesses depend on mass digital adoption as a sales channel and communications platform for their establishments to stay viable (Sidhu, 2020).

From a strategic perspective, to sustain business viability, restaurants have opted to modify their menu to feature volume-driven items that can be prepared with minimal wastage, high yield, and optimal contribution margin. At the same time, menu items must now adapt to utilise easily sourced ingredients with a long shelf life to control procurement costs and reduce wastage. This is because decision-makers face high uncertainty in inventory fulfilment as most of the suppliers offer limited choices and operate only on selected days to minimise their costs. Likewise, restaurants prefer to sell out fresh ingredients as opposed to overordering despite facing procurement difficulties. Therefore, restaurants are now putting much more emphasis on providing memorable takeaway and delivery experiences through customisation, open knowledge sharing, and personalised services. These efforts should create a more engaged and loyal customer base that will generate returning customers to shelter the losses that restaurants will endure.

\section{Conclusions}

In sum, this paper has reviewed the prominent adaptations performed by SME restaurants in Malaysia to cope with the new norm amidst the COVID-19 crisis. The authors have outlined the key adaptive measures that can be implemented by SME restaurants based upon the best practices from exemplary restaurants. From a practical perspective, this paper's outcomes will urge managers to develop effective contingency plans better and allocate funds to reduce the impact of such a crisis. On the other hand, findings from this review could theoretically and conceptually form the basis of developing a crisis management framework for SME restaurants to alleviate unexpected business environment challenges. The findings from this paper are limited to reviews from restaurants in Malaysia and target mainly independent and SME restaurants that have presented innovative adaptations to cope with the COVID19 crisis. However, encompassing both internal and external aspects of the restaurant business environment as suggested by Aguilar 
(1967) and Porter (1998) delimits this paper is proposing a holistic approach to maintain business viability within such a crisis. Hinging on the outcomes from this review, future studies can explore the differences in adaptations among large international restaurant chains and SME restaurants across different countries. Not only that, but findings from this paper also support the potential of introducing aspects of crisis management within the domain of sustaining restaurant business viability.

\section{Disclosure Statement}

No potential conflict of interest reported by the authors.

\section{References}

Aguilar, F. J. (1967). Scanning the business environment. New York: Macmillan.

Aguilera, J. M. (2017). The emergence of gastronomic engineering. Innovative Food Science and Emerging Technologies, 41, $277-$ 283. https://doi.org/10.1016/j.ifset.2017.03.017

Albors-Garrigos, J., Barreto, V., García-Segovia, P., Martínez-Monzó, J., \& Hervás-Oliver, J. L. (2013). Creativity and innovation patterns of haute cuisine chefs. Journal of Culinary Science and Technology. https://doi.org/10.1080/15428052.2012.728978

Amabile, T. M. (1988). A Model of Creativity and Innovation in Organizations. Research in Organizational Behavior. https://doi.org/Article

Amabile, T. M., Barsade, S. G., Mueller, J. S., \& Staw, B. M. (2005). Affect and creativity at work. Administrative Science Quarterly. https://doi.org/10.2189/asqu.2005.50.3.367

Anderson, N., Potočnik, K., \& Zhou, J. (2014). Innovation and Creativity in Organizations: A State-of-the-Science Review, Prospective Commentary, and Guiding Framework. Journal of Management. https://doi.org/10.1177/0149206314527128

Andersson, T. D., \& Mossberg, L. (2004). The dining experience: do restaurants satisfy customer needs? Food Service Technology. https://doi.org/10.1111/j.1471-5740.2004.00105.x

Azman, N. H. (2020). Mamak Restaurants Ponder Business Under New Normal. The Malaysian Reserve. Retrieved from https://themalaysianreserve.com/2020/04/29/mamak-restaurants-ponder-business-under-new-normal/

Bae, S., Slevitch, L., \& Tomas, S. (2018). The effects of restaurant attributes on satisfaction and return patronage intentions : Evidence from solo diners' experiences in the United States The effects of restaurant attributes on satisfaction and return patronage intentions : Evidence from solo d. Cogent Business \& Management, 5(1), 1-16. https://doi.org/10.1080/23311975.2018.1493903

Bernama. (2020). Data Expert Shares Tips Empower SMEs Surviving MCO. Malay Mail. Retrieved from https://www.malaymail.com/news/money/2020/04/15/data-expert-shares-tips-to-empower-smes-in-surviving-mco/1856966

Bernama, \& Afzanizam, M. (2020). F\&B operators navigate through MCO to sustain business. The Star. Retrieved from https://www.thestar.com.my/business/business-news/2020/04/04/fb-operators-navigate-through-mco-to-sustain-business

Bouty, I., \& Gomez, M. L. (2013). Creativity in haute cuisine: Strategic knowledge and practice in gourmet kitchens. Journal of Culinary Science and Technology. https://doi.org/10.1080/15428052.2012.728979

Bray, C. (2020). Even Hong Kong's Michelin-starred restaurants are offering takeaway menus as coronavirus forces diners to stay home. South China Morning Post. Retrieved from https://www.scmp.com/business/companies/article/3079370/even-hongkongs-michelin-starred-restaurants-are-offering

Burhan, T. (2020). Adapt your restaurant business during covid-19. Retrieved June 4, 2020, from Set The Tables website: https://setthetables.com/adapt-your-restaurant-business-during-covid-19-darren-chin/

Chan, S. M. (2020). Get Ready for a Post MCO Reset. The Star. Retrieved from https://www.thestar.com.my/business/businessnews/2020/05/01/get-ready-for-a-post-mco-reset

Chan, W. L., Hassan, W. M. W., \& Boo, H. C. (2014). The Product-related Failures in Restaurants. Procedia - Social and Behavioral Sciences, 144, 223-228. https://doi.org/10.1016/j.sbspro.2014.07.314

Che Noh, N. (2020). COVID-19: Selangor batal bazaar Ramadan (Selangor cancelled Ramadhan Bazaar). BH Online. Retrieved from https://www.bharian.com.my/berita/nasional/2020/04/671758/covid-19-selangor-batal-bazar-ramadan

Chen-Tsang(Simon), T., \& Pei-Hsun, L. (2012). Authentic dining experiences in ethnic theme restaurants. International Journal of Hospitality Management, 31(1), 304-306. https://doi.org/https://doi.org/10.1016/j.ijhm.2011.04.010

Chong, W. Y. (2012). Critical Success Factors for Small and Medium Enterprises: Perceptions of Entrepreneurs in Urban Malaysia. Journal of Business and Policy Research, 7(4), 204-215.

Choo, J. (2020). How Kuala Lumpur's F\&B industry is responding to the COVID-19 crisis. Retrieved April 25, 2020, from CNALuxury website: https://cnaluxury.channelnewsasia.com/experiences/kuala-lumpur-food-beverage-industry-covid-1912613478

Chua, B. L., Jin, N. (Paul), Lee, S., \& Goh, B. (2014). Influence of Mechanic, Functional, and Humanic Clues on Customers' Experiential Values and Behavioral Intentions in Full-Service Restaurants. Journal of Foodservice Business Research. https://doi.org/10.1080/15378020.2014.902641

CIMB Bank. (2019). SME Landscape Malaysia. Kuala Lumpur, Malaysia. Retrieved from https://www.comparehero.my/sme/articles/sme-landscape-malaysia 
Devitt, A. (2020). Comfort Food During COVID-19. Retrieved May 1, 2020, from Kerry Group website: https://kerry.com/insights/kerrydigest/2020/comfort-food-during-covid-19

Digby, M. C. (2020). Revealed: Here's how Liath's $€ 19$ Michelin-star takeaway tastes. The Irish Times. Retrieved from https://www.irishtimes.com/life-and-style/food-and-drink/revealed-here-s-how-liath-s-19-michelin-star-takeaway-tastes1.4218972

Durai, A. (2020). How established restaurants are coping with the abrupt transition from dine-in to delivery during the MCO. The Star. Retrieved from https://www.thestar.com.my/food/food-news/2020/03/29/how-established-restaurants-are-copingwith-the-abrupt-transition-from-dine-in-to-delivery-during-the-mco

Ekasari, N., Nurhasanah, N., Chairunnisa, F., \& Siregar, A. P. (2019). Model Performance Supported SMEs Strategy-Based Applications Through E-Money Gofood Business Customer Satisfaction and Grabfood. Ekonomis: Journal of Economics and Business. https://doi.org/10.33087/ekonomis.v3i2.72

Ember Modern Bistro. (2020). Ember Modern Bistro Takeaways. Retrieved June 2, 2020, from https://www.embermodernbistro.com/

Ernst \& Young. (2020). COVID-19: Impact on Malaysian businesses. Kuala Lumpur, Malaysia. Retrieved from https://www.ey.com/en_my/take-5-business-alert/covid-19-impact-on-malaysian-businesses

Eurodeli Restaurant. (2020). We Are Accepting Takeaways. Retrieved June 2, 2020, from Facebook website: http://www.eurodeli.com.my/restaurant/

Fittie Sense Restaurant. (2020). Takeaway Menu. Retrieved June 2, 2020, from Fittie Sense Restaurant. (2020). Takeaway Menu.

Gaytan, M. S. (2008). From sombreros to sincronizadas: authenticity, ethnicity, and the Mexican restaurant industry. Journal of Contemporary Ethnography, 37(3), 314-341. https://doi.org/https://doi.org/10.1177/0891241607309621

Grunebaum, D. (2020). Popular Malaysian burger chain tries to keep the sizzle during harsh economic times. VOA News. Retrieved from https://www.voanews.com/covid-19-pandemic/popular-malaysian-burger-chain-tries-keep-sizzle-during-harsheconomic-times

Hasan, A. (2019). "Jualan sempena Ramadan tak pernah mengecewakan" (Sales in conjunction with Ramadan never disappoint). Sinar Harian. Retrieved from https://www.thesundaily.my/style-life/under-the-heat-of-the-mco-NK2268168

He, H., Li, Y., \& Harris, L. (2012). Social identity perspective on brand loyalty. Journal of Business Research. https://doi.org/10.1016/j.jbusres.2011.03.007

Ismail, A. R. (2020). Under the heat of the MCO. The Sun. Retrieved from https://www.thesundaily.my/style-life/under-the-heatof-the-mco-NK2268168

Jain, S. (2020). Effect of COVID-19 on Restaurant Industry - How to Cope With Changing Demand. India. https://doi.org/http://dx.doi.org/10.2139/ssrn.3577764

Kana, G. (2020). Economic concerns as oil hits US\$20. The Star Online. Retrieved from https://www.thestar.com.my/business/business-news/2020/04/22/economic-concerns-as-oil-hits-us20\#: :text=PETALING JAYA\%3A The government will,collapse in global oil prices.\&text= "The government continues to monitor,the statement issued last night.

Kanyakumari, D. (2020). At your doorstep: More Malaysian food businesses offer delivery amid movement control order. Channel News Asia. Retrieved from https://www.channelnewsasia.com/news/asia/malaysia-covid-19-movement-control-order-foodbusiness-delivery-12570806

Kapoor, A. P., \& Vij, M. (2018). Technology at the dinner table: Ordering food online through mobile apps. Journal of Retailing and Consumer Services. https://doi.org/10.1016/j.jretconser.2018.04.001

Karim, W., \& Haque, A. (2020). The Movement Control Order (MCO) for COVID-19 Crisis and its Impact on Tourism and Hospitality Sector in Malaysia. International Tourism and Hospitality Journal, 3(2), 1-7. https://doi.org/10.37227/ithj2020-02-09

Kaur, D. (2020). Prices to remain stable post MCO. The Malaysian Reserve. Retrieved from https://themalaysianreserve.com/2020/04/21/prices-to-remain-stable-post-mco/

Kaur, K. (2020). Vegetable \& Fruit Prices Might Increase Soon Because of A Really Serious Problem. The Rakyat Post. Retrieved from https://www.therakyatpost.com/2020/04/22/vegetable-fruit-prices-might-increase-soon-because-of-a-really-seriousproblem/

Kudrowitz, B., Oxborough, A., Choi, J., \& Stover, E. (2014). the Chef as Designer: Classifying the Techniques that Chefs use in Creating Innovative Dishes. Design Research Society Conference 2014.

Lai, H. B. J., Karim, S., Krauss, S. E., \& Ishak, F. A. C. (2019). Can restaurant revenue management work with menu analysis? Journal of Revenue and Pricing Management, 18(3), 204-212. https://doi.org/10.1057/s41272-019-00194-6

Lim, S. (2020, April). Restaurant-Grade Meals At Home In Minutes: Skillet X Beta's DIY Kit. Malaysia Tatler. Retrieved from https://my.asiatatler.com/dining/restaurant-grade-meals-at-home-in-minutes-skillet-x-beta-diy-kit

Liu, M. (2020). Buy Local or Bye Local: How Malaysian food businesses are impacted by COVID-19. Retrieved April 27, 2020, from BURO website: https://www.buro247.my/lifestyle/insiders/how-malaysian-food-businesses-impacted-by-covid19.html 
Loh, G. S. (2020). Have a Michelin-starred meal delivered to your home - for a good cause. Channel News Asia2. Retrieved from https://cnalifestyle.channelnewsasia.com/dining/how-to-get-a-michelin-star-meal-delivered-to-your-home-covid-1912658188

Lynch, J., Mason, R. J., Beresford, A. K. C., \& Found, P. A. (2012). An examination of the role for Business Orientation in an uncertain business environment. International Journal of Production Economics. https://doi.org/10.1016/j.ijpe.2011.11.004

Mah, X. (2020). Serving Up Delectable Flavours During Rough Times. PR Newswire. Retrieved from https://cnalifestyle.channelnewsasia.com/dining/how-to-get-a-michelin-star-meal-delivered-to-your-home-covid-1912658188

Maharlika, F. (2020). The Dining Experience at the Pool-themed Restaurant. In Advances in Social Science, Education and Humanities Research - Proceedings of the International Conference on Business, Economic, Social Science, and Humanities - Humanities and Social Sciences Track (ICOBEST-HSS 2019). Atlantis Press. https://doi.org/https://doi.org/10.2991/assehr.k.200108.025

Mandabach, K. H., Siddiqui, M. A., Blanch, G. F., \& Vanleeuwen, D. M. (2011). Restaurant viability: Operations rating of contributing success factors. Journal of Culinary Science and Technology. https://doi.org/10.1080/15428052.2011.580707

Marcus, H. R. (2020). Dilemma for Governments. The Star. Retrieved from https://www.thestar.com.my/opinion/letters/2020/04/29/dilemma-for-governments

Mohd Zahari, M. salehuddin, Fatah, F. A., Fatah, M. O. R. A., \& Hafiz, H. M. (2017). Hotel Restaurants Ramadhan Iftar Buffet Menu Attributes, Brands and Muslim Customer Purchase Behaviour. World Applied Sciences Journal (Services Experiences and Innovation in Hospitality \& Tourism), 35, 53-58. https://doi.org/10.5829/idosi/wasj.seiht.2017.53.58

Mohsen, Am. S. (2020). MCO: No change in SOP during Ramadan, eateries to remain closed for sahur. TheSundaily. Retrieved from https://www.thesundaily.my/local/mco-no-change-in-sop-during-ramadan-eateries-to-remain-closed-for-sahurCD2324004

National Security Council. (2020). Movement Control Order: FAQ \& Info. Retrieved April 24, 2020, from Prime Minister's Office of Malaysia Official Website website: https://www.pmo.gov.my/2020/03/movement-control-order-faq-info/

New Straight Times. (2020). \#JOM! Eat: Nando's making a difference one chicken at a time. New Straits Times. Retrieved from https://www.nst.com.my/lifestyle/jom/2020/04/584506/jom-eat-nandos-making-difference-one-chicken-time

Osterwalder, A., \& Pigneur, Y. (2010). Business Model Generation: A Handbook for Visionaries, Game Changers, and Challangers. In Booksgooglecom.

Ottenbacher, M., \& Harrington, R. J. (2007). The innovation development process of Michelin-starred chefs. International Journal of Contemporary Hospitality Management. https://doi.org/10.1108/09596110710775110

Ozdemir, B., \& Caliskan, O. (2014). A review of literature on restaurant menus: Specifying the managerial issues. International Journal of Gastronomy and Food Science, 2(1), 3-13. https://doi.org/10.1016/j.ijgfs.2013.12.001

Perry-Smith, J. E., \& Mannucci, P. V. (2017). From creativity to innovation: The social network drivers of the four phases of the idea journey. Academy of Management Review. https://doi.org/10.5465/amr.2014.0462

Pine, B. J., \& Gilmore, J. H. (1998). Welcome to the experience economy. Harvard Business Review.

Porter, M. E. (1998). The Competitive Advantage: Creating and Sustaining Superior Performace (1st ed.). Harvard Business School Press.

Ramos, J., Anderson, N., Peiró, J. M., \& Zijlstra, F. (2016). Studying innovation in organizations: a dialectic perspectiveintroduction to the special issue. European Journal of Work and Organizational Psychology, 25(4), 477-480. https://doi.org/10.1080/1359432X.2016.1192364

Rathod, A., Khadke, A., Wakode, C., Ubnare, P., \& Shinde, C. (2018). Food finder - Mobile food ordering application. International Journal of Advance Research, Ideas and Innovations in Technology.

Ryu, K. (2011). New or repeat customers: How does physical environment influence their restaurant experience? International Journal of Hospitality Management, 30(3), 599-611. https://doi.org/10.1016/j.ijhm.2010.11.004

Severson, K., \& Moskin, J. (2020). Restaurants Across the Country Struggle to Respond to Coronavirus. The New York Times. Retrieved from https://www.nytimes.com/2020/03/12/dining/restaurants-coronavirus.html

Sidhu, K. K. (2020). Covid-19 brings about mass digital adoption. Digital News Asia. Retrieved from https://www.digitalnewsasia.com/digital-economy/covid-19-brings-about-mass-digital-adoption

Slavich, B., \& Svejenova, S. (2016). Managing Creativity: A Critical Examination, Synthesis, and New Frontiers. European Management Review. https://doi.org/10.1111/emre.12078

SME Corp. (2016). Guideline For New SME Definition. Malaysia. Retrieved from https://www.smecorp.gov.my/images/pdf/Guideline_New_SME_Definition_updated.pdf

Sousa, F., Pellissier, R., \& Monteiro, I. (2012). Creativity, innovation and collaborative organizations. The International Journal of Organizational Innovation.

Sukalakamala, P., \& Boyce, J. B. (2007). Customer perceptions for expectations and acceptance of an authentic dining experience in Thai restaurants. Journal of Foodservice. https://doi.org/10.1111/j.1745-4506.2007.00048.x

Surendran, S. (2020). SMEs and Gig Economy Bear Brunt MCO. The Edge Markets. Retrieved from https://www.theedgemarkets.com/article/cover-story-smes-and-gig-economy-bear-brunt-mco 
Tan, A. (2020). Covid-19 Measures: Saint Pierre Gets Creative And Offers Fine Dining Over A Zoom Call. Singapore Tatler. Retrieved from https://sg.asiatatler.com/dining/covid-19-saint-pierre-gets-creative-fine-dining-zoom-call

Taylor, J. J., \& Brown, D. M. (2007). Menu analysis: A review of techniques and approaches. Hospitality Review, 25(1985), 6.

Trupthi, B., Rakshitha Raj, R., Akshaya, J. B., \& Srilaxmi, C. P. (2019). Online food ordering system. International Journal of Recent Technology and Engineering. https://doi.org/10.35940/ijrte.B1156.0782S319

Uman, D. (1983). Pricing for Profits. Restaurant Business.

Unsworth, K. (2001). Unpacking Creativity. The Academy of Management Review. https://doi.org/10.2307/259123

Vargas-Sánchez, A., \& Lopez-Guzman, T. (2015). Contemporary management and innovation: Learning from the gastronomy sector. Journal of Food, Agriculture and Environment.

Walls, A. R., Okumus, F., Wang, Y. R., \& Kwun, D. J. W. (2011). An epistemological view of consumer experiences. International Journal of Hospitality Management. https://doi.org/10.1016/j.ijhm.2010.03.008

Wan, Di. (2020). Overcoming The Pandemic. How One Restaurant Found A Win-Win Solution. Retrieved April 30, 2020, from iCHEFMalaysia website: https://www.ichefpos.com/en-my/blog/6ztttiixm1iczg9shtkgb5saue7g2q

Wei, J. Y. . (2020). Elevate Your MCO Meals With These Gournet Food Deliveries. Unreserved Media. Retrieved from https://www.unreservedmedia.com/elevate-your-mco-meals-with-these-gourmet-food-deliveries/

Whitehead, R. (2020). Malaysian SMEs feel neglected by government's latest COVID-19 stimulus. Retrieved April 30, 2020, from SalaamGateaway website: https://salaamgateway.com/story/malaysian-smes-feel-neglected-by-governments-latest-covid19-stimulus

Yap, C. (2020). Flipping burgers and warming hearts. The Star. Retrieved from https://www.thestar.com.my/news/nation/2020/04/09/flipping-burgers-and-warming-hearts

Yi, L. K. (2020). Covid-19: Malaysian F\&B operators fighting to stay alive by being innovative with their delivery menus. Malay Mail. Retrieved from https://www.thestar.com.my/news/nation/2020/04/09/flipping-burgers-and-warming-hearts

Zainal Abidin, M. R., Che Ishak, F. A., Ismail, I. A., \& Juhari, N. H. (2020). Modern Malaysian Cuisine: Identity, culture, or modern-day fad? International Journal of Gastronomy and Food Science, 21. https://doi.org/10.1016/j.ijgfs.2020.100220 